\title{
PEACE PROCESS IN KOREAN PENINSULA: PROSPECTS AND CHALLENGES
}

\author{
Summar Iqbal Babar* \\ Imran Ali Sandano ${ }^{+}$ \\ Syed Fraz Hussain Naqi ${ }^{\ddagger}$
}

\begin{abstract}
The peace process in the Korean Peninsula is one of the pivotal issues for international security. The burgeoning nuclear programme of North Korea, relief in sanctions and the presence of US forces are the daunting challenges for the peace and strategic stability in the Korean Peninsula. For that purpose, different measures, ranging from diplomatic efforts to global sanctions, have been taken. The reinitiating of the peace process in 2017, which involved the intra-Korean negotiations and Trump-Kim Summits have given a positive yet fragile signal. However, the peace process involves various steps, compromises, and flexibilities. For the peace process, the normalisation of relations between North Korea and the US is of colossal significance. The confidence-building measures need to be adopted by both sides. This paper aims at highlighting the issues and evaluating the possible outcomes of the peace process in the Korean Peninsula.
\end{abstract}

Keywords: Korean Peninsula, International security, Conflict resolution, Nuclear proliferation

\section{INTRODUCTION}

North Korea has made a vivid transformation in its foreign policy approach after its leader, Kim Jong Un, met the leaders of the world including the president of the United States, China, South Korea, and

\footnotetext{
"Assistant Professor at School of Politics and International Relations, Quaid-i-Azam University. Email: summar.rao@qau.edu.pk (Corresponding author).

${ }^{+}$Assistant Professor, Department of International Relations, University of Sindh. Email: iimran110@usindh.edu.pk

$\ddagger$ MPhil scholar at National Defense University. Email: frazashhab@gmail.com
} 
Russia (Katzeff, 2019) for the settlement of North Korea's nuclear programme. The acquisition of nuclear capability by North Korea has long threatened the stability and peace in the Korean Peninsula. In 2017, North Korea conducted its sixth nuclear test and a successful inter-ballistic missile test, which can reach the United States (Feickert, Manyin, Hildreth, Nikitin, \& Chanlett-Avery, 2017). So far, various efforts have been made for the peaceful settlement of the North Korean Nuclear Programme, which bore minimum fruits.

In 2018, Donald Trump met Kim Jong Un and both agreed to carryout efforts for bringing peace and stability to the Korean Peninsula. Although the process was going swiftly, yet the Vietnam Summit ended in a disaster that depicted the trust deficit between the two states (Tokala, 2019). The differences arose when the US decided to dismantle the Korean Nuclear Programme while North Korea insisted on making the peace treaty before dismantling.

The trust deficit has arisen due to the unpredictable nature of the leaders of the US and North Korea. The increasing threats of nuclear missiles by Kim Jong Un has made him a nuclear-obsessed leader before the international community. On the other hand, the previous examples of Iraq and Libya, in which the US first dismantled their nuclear programmes and then overthrew the regimes of Saddam and Gaddafi respectively, make the US suspicious in the eyes of North Korea. However, without the participation of the US, the peace treaty is not feasible because of two main reasons. First is the economic sanctions on North Korea in which the US has a major role to play while the other is the linkage of Inter-Korean Negotiations with that of the US as South Korea is under the extended security umbrella of the US.

Apart from the nuclear issue, the deployment of US troops in the Korean Peninsula has also added to the instability of the region (Sokolsky, 2019). The US military presence has created the sense of the fear among the elements of North Korean regime. This has 
provoked North Korea to maximise its military capabilities. The advancement in nuclear technology and the missile tests conducted by North Korea have brought it towards the collision course with the regional countries - mainly South Korea and Japan. Since Japan shares the apprehensions regarding North Korea - especially, when it has the imperial legacy with the regional states like China as well. Furthermore, the peace process in the Korean Peninsula is objectively expected towards the prospects of unification of Korea. However, the discrepancies in the political and economic systems of North Korea and South Korea have lessened the likelihoods of unification.

The role of China is quite significant as well as it tends to employ the peace process in four phases. Firstly, North Korea which includes the cessation of the North Korean Nuclear Programme and followed by the termination of US-South Korea Military Exercises, which threaten the North Korean security. After that, the third step would be to integrate North Korea into the mainstream international community, and once, it becomes a part; the final step would be to sign the peace treaty. Hence the basic questions, which this study addresses, are:

- Is peace possible between North Korea and South Korea?

- How far the role of the US is significant in bringing peace to the Korean Peninsula?

The qualitative content analysis approach has been employed to investigate these questions. Through this approach, the grievances of US, North Korea and other regional states can be better comprehended and the obstacles, which hinder the peaceful settlement, has been highlighted.

\section{THEORETICAL FRAMEWORK}

To understand the peace process in the Korean Peninsula and its vitality, this study has employed Regional Security Complex Theory and Conflict Management approaches as theoretical frameworks. 


\section{Regional security complex theory}

Regional Security Complex Theory (RSCT), proposed by Barry Buzan and Ole Waever (2003), views that there are various regional security complexes (RSCs) in the world. It defines that a regional security complex is usually based upon a set of units whose major processes of securitization, de-securitization, or both are so interlinked that their security problems cannot reasonably be analysed or resolved apart from one another. There is the serious security interdependence between these units. Also, these RSCs are at play in an anarchic international system and the balancing behaviour can be observed within the complexes.

According to the regional security complex theory, if one state goes for its security in a region, it compels other states to securitise themselves. This simply explains that if North Korea were becoming nuclear, South Korea and Japan would also feel tempted to acquire the capability of deterrence. The nuclear capability of North Korea provokes the security concerns in the region and makes it volatile. Theoretically, this compliments the concept of Balance of Power, which is the main ingredient of this theory. However, apart from the regional level, nuclear issue extends beyond the regional boundaries as US is a major advocate of the denuclearisation of the Korean Peninsula. The US interests in the region mainly stem from its extended security, which it provides, to both Japan and South Korea. Hence, under the framework of this theory, US also has the part to play.

\section{Conflict management approach}

The appropriate choice to decipher the crises occurring in the Korean Peninsula is conflict management approach. It is an effort to control or contain an ongoing conflict between politically motivated actors operating at the state or sub-state level typically through the involvement of a third party. The third party employs four different 
kinds of approaches when managing conflict. These approaches include the threat-based approach (use or threat of force), deterrencebased approach (coercive diplomacy), adjudicatory approach (legal settlements), and accommodations approach (traditional and nontraditional diplomatic means to broker agreement) (Brown, 1992).

There are three required modalities when managing a conflict i.e. nature, culture, and structure. These three things significantly influence the conflict. Nature describes the cognitive setup, which evaluates and reshapes the view while the culture is the amalgamation of values and norms. Structure, on the other hand, is more materialistic, which involves the system comprised of institutions and their functioning at both national and international levels. For general reference, it is the global environment, in which the states interact with each other. In the case of North Korea and South Korea, the natural factor can be seen as the North Korean leader is authoritative and has the war-oriented policies focusing on its security while the South Korean President is democratic and is prone to peace in the region and believes in the co-existence of both states. Culture plays an important role as Kim's personality is like his father and grandfather because these realistic norms are inserted into his personality. On the other hand, President Moon Jae is progressive in its thinking (Kathryn, 2020).

Structure tends to influence the domestic system of a state to survive in an anarchic world system. As North Korea has gained the nuclear capability to survive the threats of aggressive states. Similarly, South Korea has also sought an alliance with a powerful state like the US for its security. To survive in the competitive environment, states acquire weapons.

The US has somehow managed the conflict, as there is no full-scale war on the Korean Peninsula since 1953. The three states i.e. North Korea, South Korea, and the US are the three important actors on the Korean peninsula, which have their respective interests in the peace 
process. It would help South Korea's President Moon in improving his country's burgeoning relationship with the North and would pave the way for a formal peace treaty. For Kim, a peace declaration would further consolidate his regime and reduces the chance of war with the United States. For US, it would make the way for real denuclearization efforts on the Peninsula.

\section{HISTORICAL BACKGROUND}

North Korea and South Korea emerged on the world map after World War-II. Before this, Korea remained under the Japanese rule for thirtyfive years (Lee, Ha \& Sorensen, 2013). In 1948, the UN-sponsored election took place, whose objective was to decide the future of the Korean Peninsula in which North Korea did not participate in the election process and South Korea formed its government in Seoul backed by the US. Following this, North Korea also formed its government and Kim II Sung became the first president of the Democratic People's Republic of Korea. Soon after their independence, both countries went into a war, which is famously known as the Korean War of 1950-1953.

As the war occurred in the cold war environment, both North and South Korea were backed by Russia and the US respectively. Finally, after three exhausting and rapacious years, the armistice treaty known as The Korean War Armistice Agreement 1953, was signed and the division took place along the $38^{\text {th }}$ Parallel. Hence, the armistice treaty does not ensure the peace and the division eventually divided the Korean Peninsula having two different ideologies and worldviews.

Since then, North Korea has a dictatorial form of government while South Korea is a democratic country. The political divide between both countries is one of the inevitable hurdles in the process of reunification. Moreover, in terms of economics, North Korea lags behind South Korea that is industrialised. The security factor also 
plays an overarching role as North Korea is now nuclearized while South Korea is still under the security umbrella of the US.

Among all the hurdles in the process of reunification, the nuclear issue is the pivotal one. When South Korea was focusing on its economy and infrastructure, North Korea was involved in making itself nuclear power to resist the US. North Korea joined the nuclear proliferation treaty (NPT) in 1985 (Gershman \& Huntley, 2005) and withdrew from it in 2003 and conducted its first nuclear test in 2006. The main factor was the dismemberment of the USSR. As USSR was the major security guarantor of North Korea, its demise created a security dilemma for North Korea, which eventually led it to attain nuclear capabilities to safeguard its territorial integrity and regime's survival.

The nuclear debate between North Korea and South Korea, in fact, it far exceeds the regional boundaries and is now considered an international issue. First, the other essential contender of nuclear capability is Iran in the Middle East. The international community is already in a state of disarray since the withdrawal of US from the Iran Nuclear Deal, otherwise known as Joint Comprehensive Plan of Action (JCPOA) in 2018. The uranium enrichment by Iran means that the threat of nuclearisation is still looming over the world. The main issue is not of Iran's nuclear capability, instead, it is of domino effect that could lead to the nuclearization of the entire region since other states like Saudi Arabia and United Arab Emirates would feel threatened. Similarly, if the US failed to communicate with North Korea effectively, the regional states like Japan and South Korea would be compelled to take action on their own and they may find the necessity of getting nuclear. Hence, international security in this would be affected due to the change in the status quo.

\section{Comparing North Korea and South Korea capabilities}

The comparison of both the states is carried out in two terms i.e. economically and militarily, which is as under: 


\section{Economic capabilities}

South Korea is an advanced technological and industrialised country while North Korea remains underdeveloped. The colossal difference lies in the economic structure of both nations. While South Korea gradually restructured its economy and adopted the capitalist model of the economy, North Korea strictly adhered to the communist ideology and the economic activities largely remained under the control of the state.

Today, South Korea is the world's twelfth largest economy with a per capita income of about 31,000 USD (Silver, 2020), and is leading the world in shipbuilding and manufacturing consumer electronics and cars. South Korea made vivid and promised progress in opening up its economy to the world and became a peculiar example for the third world to excel in becoming the first world nation along with Japan and China.

As for North Korea, the regime has been focusing on the military sector with 1.3 million active-duty troops and has become one of the world's largest ground forces (Soek, 2020). Apart from that, North Korea is also a formidable nuclear power with the missile capabilities that can hit anywhere around the globe. Due to this inward-looking approach, international trade is strictly limited. However, the North Korean government's policy of self-help and isolationism has failed badly. Due to its policy, the infrastructure remained redundant and the institutions remained underdeveloped except the military.

\section{Military capabilities}

While comparing both the states in military terms, North Korea has focused on quantity rather than quality while the Republic of Korea has focused on quality rather than quantity. South Korea has gained the support of the US and is virtually under the influence of the US security umbrella. According to the mutual defence treaty between the US and South Korea, 28,500 US troops are present in South Korea 
(D’Ambrogio \& Yang 2020). It has improved conventional forces by increasing lethality with improvements in command, control, communication, and advanced technology.

The number of military troops of South Korea is half of the North Korean troops as South Korea has the strength of approximately 490,000 troops along with the combined US troops of 70,000 on ground and waters. On the other hand, North Korea has the fourthlargest army in the world. It possesses biological and chemical weapons along with nuclear capability. It has invested in asymmetric capabilities including both weapons of mass destruction and special operation forces. At the ground level, North Korea has 4200 tanks, 2200 armed vehicles, 8600 field artillery, and 5500 multiple rockets. In its air force, North Korea has over 800 combat aircraft, 300 helicopters, and over 300 transport aircraft. North Korea also has a strong naval force with 70 submarines, 430 patrol combatants, 260 amphibious landing craft, 20 mine warfare vessels, and 40 auxiliary vessels (Soek, 2020).

\section{Role of the US in the peace process}

The US has been working in bringing peace to the Korean Peninsula. The process started in 1994 when the Clinton administration tried to formulate the deal with North Korea. The basic tenets of the framework were that North Korea would shed and shun the construction of graphite-moderated nuclear reactors in-exchange for US help in the construction of 1000 megawatt light water reactors with a total amount of four billion dollars (Kim, 2008).

Two main reasons contributed to the agreement of North Korea in negotiating the framework with the US. The first one was the demise of the USSR, which made North Korea devoid of USSR support while the second was Chinese growing relations with South Korea, North Korea's main rival. Hence, for its security interests, North Korea had to reach out to the US. However, the agreement could not last long as the US failed to fulfil its promises. The only achievement of the 
agreement was the relatively lesser animosity between the US and North Korea.

However, after the 9/11 attacks, the relations again took the downturn as US President G.W. Bush marked North Korea in the 'Axis of Evil' along with Iraq and Iran. Following the threats by the US, North Korea withdrew from the NPT in 2003. This led to the US requesting China to mediate between the US and North Korea. China agreed and decided to play its role as a mediator and will make the table talks easy for both parties. On the insistence of the US, the other major players were also involved which included Japan, Russia, and South Korea, and hence the six-party talks were convened in Beijing.

The dialogue, however, again failed in 2009 for three main reasons. One was the North Korean Nuclear Tests in 2006, the second was the economic sanction imposed by the US and the final was again the harsh economic sanctions in response to satellite launch by North Korea. Furthermore, the US was not willing to lift the economic sanctions as a precondition to talks while for North Korea, nuclear negotiations and lifting of economic sanctions were inseparable.

The efforts were started in 2018 when in a drastic turn of events, the intra-Korean Summit took place between North Korea and South Korea. Furthermore, Kim Jong Un took its first foreign official trip to China and discussed the peace prospects in the Korean Peninsula. In this regard, two summits between US President Donald Trump and North Korean Leader Kim Jong Un took place in Singapore and Hanoi respectively. The four major postulates of the summit included the initiation of diplomatic relations between the two states, peace in the Korean Peninsula, denuclearization, and return of POW/MIA. North Korea fulfilled its promises by destructing a rocket launcher site and shutting down the ICBM facility. However, the Hanoi Summit failed and proved to be the cornerstone of cessation of further talks between the two states. North Korea expected to find relief in terms of the partial uplifting of sanctions to which the US was not ready before the 
complete denuclearization. Hence, the agreement was not reached and the relations remained tensed afterwards (Lee, 2019).

Conclusively, the US has two options regarding its policy for North Korea. First, it should accept North Korea as nuclear power and rely on deterrence to lower the risk of any attack. But this option of acceptance would eventually provoke other regional states like Japan and South Korea to rethink about their non-nuclear postures. This could lead to the nuclearization of that region. Along with this, the acceptance of North Korea as a nuclear state will damage the image of the non-proliferation treaty (NPT), which North Korea joined in 1985 and withdraw from it in 2003.

The second possible option is that the US should come up with diplomacy that is more creative. It should work a plan that would figure out the mechanism to resolve any difference. It should give such incentives that compel North Korea to freeze its nuclear programme or make an interim agreement that if North Korea will freeze its nuclear programme US will remove sanctions. Unless the US is not willing to show flexibility on its part, North Korea would remain sceptical of US intentions due to its past record in Libya and Iraq. Reaching a deal with North Korea could also boost the US image internationally, which has been sabotaged by its withdrawal from JCPOA.

\section{Challenges to the peace process in Korea}

The peace process in Korea was stopped a long time ago, but it is restated again. The North Korean leader now agreed to come on the table for a peaceful settlement of the conflict. It may be due to the sanctions imposed by the UN or due to military threats of the US. Despite this, there are many challenges to the peace process or in other words to the unification process because the peace process will eventually lead to the reunification of the Korean peninsula. Those challenges are as follows: 


\section{North-South Divide}

The first and foremost problem is the division between the two Koreans also has different political set-ups. North Korea is an authoritative communist regime that is very unpredictable. This element of unpredictability can create hurdles in the peace process. Secondly, the regime's determination to continue its system and its dependence on military power is another problem. If peace is achieved on the Korean Peninsula, then the question of who will be dominating unified Korea will be of vital importance. The striking difference between the military and economic power would make it quite difficult for both the states of North Korea and South Korea to come under the influence of each other.

Moreover, the president of South Korea in one speech has clearly said that they wanted the unification of Korea in which South Korea will be taking the lead (Pacific, 2018). This question of who will be taking the lead will again give rise to the conflict because of the different political structures of both states. South Korea is the antithesis of what North Korea is today. This difference in political structure will create hurdles for continuation if the unification is achieved.

\section{Presence of US Troops}

The presence of US troops on the Peninsula will be the main question because if the peaceful settlement is to take place between North Korea and South Korea then the troop's withdrawal is significant. It can be compared with the peace process in Afghanistan in which the US agreed to withdraw its military presence to ensure the Taliban regime of its true intentions of peace (Ruger \& Rajan, 2020). Similarly, US military withdrawal from the Korean Peninsula is the pretext for achieving peace. The troop's withdrawal will not be an easy task as it is the security guarantor for South Korea. Hence, the mechanism would have to be adopted as such that South Korean security will not be compromised by this step. 


\section{Disarmament}

Another challenge is that of the disarmament of the Korean Peninsula for peaceful co-existence. The issue of disarmament could create hurdles in the peace process. North Korea employees its nuclear capability to threaten South Korea and even to the US. In the meantime, the US is asking for the denuclearization of North Korea but is not removing sanctions that are being perceived by suspicion by North Korea. For its security purposes, if North Korea keeps its nuclear programme functioning or partially functioning, it would create a complex situation for every actor in the region. Even if the peace treaty were signed under such circumstances, its viability would still have questionable consequences.

\section{Role of China}

If peace is to be achieved in the Korean Peninsula, the concerns of China ought to be resolved. China can prove to be a hindrance in the peace process due to the overwhelming dependence of the US over China to shape the behaviour of North Korea. China shares the US concerns of denuclearization of North Korea but the pressure it can exert over North Korea has its limits. Hence, China's reluctance to subscribe to US demands in the Korean peace process is questionable which can affect the whole process.

\section{Japan- Korea rift}

The memories of imperial Japan for Koreans are still fresh. The practical demonstration is in the form of territorial disputes between Japan and South Korea on islands. This has always been the contentious issue between the relations of the two states. Furthermore, the withdrawal of South Korea from the "intelligencesharing deal" has further deteriorated the relations between the two states (Withnall, 2019). In the wake of North Korea's 2016 missile tests, both Japan and South Korea came into the agreement with each other to jointly share the information regarding North Korea. 
However, the South Korean withdrawal after the North-South Summit raised the issue of mistrust between Japan and South Korea. Furthermore, the withdrawal of US troops from the Korean Peninsula in the wake of peace process might also irk Japan as US troops were the main source of satisfaction for Japan. In order to achieve the sustainable peace, the regional issues also need vital attention otherwise, even if the intra-Korean relations gets better, other states might continue to share their apprehensions.

\section{CONCLUSION}

There is no doubt that North Korea and South Korea are making history when President Kim Jong met President Moon Jae. This was the historic meeting between the two leaders. However, from this meeting and Kim's meeting with Trump, it cannot be concluded that peace is achieved on the Korean peninsula. This type of historic meeting was also seen in the past between Kim Dae Jung and Kim Jong-II in 2000 and ended without achieving peace.

The two-track approach is needed for peace on Korean Peninsula. One is inter-Korean track and the second is the international track. Inter-Korean relations are getting better, but the international approach is lacking behind, as the US believes that peace can be attained through complete denuclearization of North Korea, which is not possible in near future. North Korea is not willing to dismantle its nuclear program because of its apprehensions after observing the fates of Saddam and Gaddafi. This objective is now difficult to achieve because of the nuclear capability of North Korea but once North Korea dismantles its nuclear program the US can easily take over it.

According to the paradigm of realism, there are three important things for a state; statism, self-help, and survival. In statism, the state is the main player in the international system and states do the things that fulfil their national interests. In the present situation North Korea nuclear program is serving the national interest of the state. North 
Korea's nuclear program is the manifestation of self-help. The statelevel of power is influenced by military and economic capabilities. The state that is lacking behind in the economy has an edge over the other states that are more developed than it because of nuclear capability. No state can militarily intervene in North Korea because of the fear of nuclear weapons. North Korea has attained a balance of power due to its nuclear capability.

Nuclear capability is the reason that other states are asking for dialogue with North Korea. North Korea's nuclear capability has provided a military edge to it over the well-developed economic states. The international system is anarchic, and the state has to survive on its own. It can never trust another state to guarantee its survival so far the survival of North Korea nuclear capability is necessary. What the future holds regarding the peace process is uncertain but keeping these things in mind one can conclude that peace is not possible on the Korean Peninsula in near future?

\section{REFERENCES}

Brown, L. D. (1992). Normative conflict management theories: Past, present, and future. Journal of Organizational Behavior, 13, 303309.

Buzan, B., \& Waever, O. (2003). Regions and powers; The structure of international security. Cambridge: Cambridge University Press.

D'Ambrogio, E., \& Yang, M. (2020). Korean Peninsula: State of play: Further uncertainty follows period of hope. Brussels : European Parliamentary Research Service.

Feickert, A., Manyin, M. E., Hildreth, S. A., Nikitin, M. B. D., \& Chanlett-Avery, E. (2017). The North Korean nuclear challenge: Military options and issues for congress. Washington D.C: Congressional Research Service. 
Gershman, J., \& Huntley, W. L. (2005). North Korea \& the NPT. Institute for Policy Studies. Retrieved from https://ips-dc.org /north_korea_the_npt/

Katzeff, B. (2019). Kim Jong-un is meeting woth world leaders, but does it matter? Retrieved from https://www.fpri.org/article/2019/ 05/kim-jong-un-is-meeting-world-leaders-but-does-it-matter/

Kim, I. (2008). A Comparative analysis of president Clinton and Bush's handling of the North Korean nuclear weapons program: Power and strategy. Pacific Focus, 69-106.

Lee, H.Y., Ha. Y.C. A., \& Sorensen, C.W. (2013). Colonial rule and social change in Korea, 1910-1945. Washington D.C: University of Washington Press.

Lee, S. H. (2019). Denuclearizing North Korea: Challeneges and opportunities after Hanoi. Focus Asia; Perspective and Analysis, 1-9.

Pacific, East Asia. (2018, April 24 ). A unified Korea? Leaders bring contrasting visions to summit. Reteived from https://www.voanews.com/east-asia-pacific/unified-korealeaders-bring-contrasting-visions-summit

Ruger, W., \& Rajan, M. (2020, November 18). It's time to withdraw from Afghanistan, The Washington Post. Retreived from https://www.washingtonpost.com/opinions/2020/11/17/willia m-ruger-rajan-menon-withdraw-us-troops-afghanistan/

Silver, C. (2020, March 18). The top 20 economies in the world. Retrieved from https://www.investopedia.com/insights/ worlds-top-economies/

Soek, K. M. (2020). The state of the North Korean military . In C. M. Lee \& K. Botto (Eds.). Korea net assessment: Politicized security and unchanging strategic realities (pp. 19-28). Washington D.C: Carnegie Endowment for International Peace. 
Sokolsky, R. (2019). Building peace and security on the Korean Peninsula: Whither the US-South Korean alliance? Special Report, Washington DC: Stimsom Centre.

Tokala, M. (2019). The Hanoi summit; A point on a long North Korean foreign policy line. Washington D.C: the national bureau of asian research.

Withnall, A. (2019, August 23). Japan lashes out at South Korea as worst relations in decades threaten North Korea peace talks. Retreived from https://www.independent.co.uk/news/world/ asia/japan-south-korea-intelligence-deal-north-nuclearweapons-peace-shinzo-abe-a9076271.html -(1953, July 27). The Korean War Armistic Agreement Retrieved from https://www.usfk.mil/Portals/105/Documents/SOFA/ G_Armistice_Agreement.pdf 